\title{
PENEKANAN HAYATI PENYAKIT MOLER PADA BAWANG MERAH DENGAN TRICHODERMA HARZIANUM, TRICHODERMA KONINGII, DAN PSEUDOMONAS FLUORESCENS P60
}

\author{
Suprapto Edy Santoso ${ }^{1}$, Loekas Soesanto ${ }^{2}$, dan Totok Agung Dwi Haryanto ${ }^{3}$
}

\begin{abstract}
Biological Suppression of Moler Disease on Shallot by Trichoderma harzianum, Trichoderma koningii, and Pseudomonas fluorescens P60. Research aiming for (1) knowing efectivity of biological suppression with $T$. harzianum, $T$. koningii, and P. fluorescens P60 and (2) studying growth and production of shallot caused by the suppression carried out at the shallot farm. Split-Split Plot Design arranged in Randomized Completely Block Design was used with three replicates. The research result showed that $P$. fluorescens $\mathrm{P} 60$ was the most effective antagonistic agent to suppress the disease either alone or in combination while T. harzianumi and T. koningii did not suppress effectively. Pseudomonas fluorescens $\mathrm{P} 60$ could suppress the disease up to $41.96 \%$. The best method of $P$. fluorescens $\mathrm{P} 60$ application was spraying method for $10 \mathrm{~mL}$ with $10^{7} \mathrm{cfu} / \mathrm{mL}$ population density, which was able to dicrease incubation period, disease intensity, and final pathogen population up to $62.46,18.19$, and $80.67 \%$, respectively. Growth and production of the crop tended to increase resulted from biological suppression by $P$. fluorescens P60, but not by T. harzianum nor T. koningii.
\end{abstract}

Key words: Fusarium oxysporum, Trichoderma harzianum, Trichoderma koningii, Pseudomonas fluorescens P60, biological suppression

\section{PENDAHULUAN}

Bawang merah (Allium ascalonicum L.) merupakan tanaman sayuran yang memiliki banyak manfaat bagi kehidupan manusia. Hal tersebut menyebabkan permintaan bawang merah terus meningkat. Luas panen pertanaman bawang merah di Kabupaten Tegal pada tahun 2004 adalah 1.034 hektar dengan produksi rata-rata 92,8 ku/ha (Badan Pusat Statistik, 2004).

Serangan patogen tanaman merupakan salah satu kendala yang sering dihadapi dalam budidaya bawang merah. Salah satu penyakit yang sering dijumpai pada tanaman bawang merah adalah penyakit moler, yang diduga disebabkan oleh Fusarium oxysporum (Departemen Pertanian, 2003). Besarnya kerugian yang ditimbulkan oleh penyakit moler belum diketahui secara pasti karena terbatasnya informasi penyakit tersebut. Oleh karena itu, diperlukan penelitian yang mampu memberikan informasi mengenai penyakit moler pada bawang merah.

Usaha pengendalian penyakit moler pada saat ini masih ditekankan pada teknik pengendalian dengan menggunakan fungisida. Akan tetapi, saat ini diperlukan pengendalian penyakit yang aman, murah, dan ramah lingkungan. Salah satu pilihan pengendalian yang tepat dan perlu diupayakan adalah pengendalian dengan menggunakan agensia hayati, seperti Trichoderma harzianum, T. koningii, dan Pseudomonas fluorescens P60. T. harzianum mampu menekan $F$. oxysporum f.sp. gladioli penyebab layu pada tanaman gladiol (Rokhlani, 2005) dan F. oxysporum f.sp. zingiberi (Soesanto et al., 2005; Prabowo et al., 2006). Selain itu, T. harzianum dan $T$. koningii juga mampu mengendalikan jamur Rigidoporus microporus pada tanaman karet (Basuki, 1986 dalam Sudantha, 2003). Sementara itu, $P$. fluorescens P60 banyak digunakan untuk pengendalian hayati patogen tular-tanah (Soesanto, 2000; Soesanto \& Termorshuizen, 2001; Soesanto et al., 2003; Rokhlani, 2005).

Upaya penekanan hayati terhadap serangan penyakit tanaman bawang merah menggunakan agensia hayati jarang dilakukan petani. Oleh kerena itu, perlu dilakukan penelitian penekanan hayati terhadap penyakit moler pada bawang merah. Tujuan penelitian adalah (1) mengetahui keefektifan penekanan hayati dengan $T$. harzianum, $T$. koningii, dan $P$. fluorescens P60 baik tunggal atau gabungan terhadap penyakit moler dan (2) mengkaji pertumbuhan dan produksi bawang merah akibat penekanan hayati oleh $T$. harzianum, $T$. koningii, dan $P$. fluorescens $\mathrm{P} 60$ baik tunggal atau gabungan.

\footnotetext{
${ }^{1}$ Staf Dinas Pertanian, Perkebunan \& Kehutanan Kabupaten Tegal

${ }^{2}$ Dosen Program Studi Ilmu Hama dan Penyakit Tumbuhan Fakultas Pertanian Universitas Jenderal Soedirman, Purwokerto e-mail : lukas_262@yahoo.com.

${ }^{3}$ Dosen Program Studi Pemuliaan Tanaman Fakultas Pertanian Universitas Jenderal Soedirman, Purwokerto.
} 


\section{METODE PENELITIAN}

Penelitian dilaksanakan di lahan pertanian bawang merah di Desa Kedokansayang, Kecamatan Tarub, Kabupaten Tegal, dari bulan April sampai Juni 2006.

Penyiapan bahan. Benih bawang merah varietas lokal Bima dari Brebes sebanyak 8,82 kg digunakan dengan dipotong bagian ujungnya $\pm 1 / 3$ bagian (Direktorat Perlindungan Hortikultura, 2001). Ukurannya seragam dengan berat masing-masing $5 \mathrm{~g}$.

Penyiapan isolat. Isolat antagonis T. harzianum dan $T$. koningii diisolasi langsung dari bawang merah sakit, sedangkan isolat $P$. flourescens $\mathrm{P} 60$ dari koleksi (Soesanto dan Termorshuizen, 2001), yang semuanya disiapkan masing-masing dalam medium PDA untuk jamur antagonis dan King's B untuk bakteri antagonis. Isolat jamur patogen $F$. oxysporum diisolasi dari umbi bawang merah sakit pada medium PDA ditambah streptomisin $100 \mathrm{ppm}$. Perbanyakan isolat jamur antagonis dan patogen dilakukan dalam medium kentang dekstrosa cair (Potato Dextrose Liquid atau PDL) (Tuite, 1969), yang dikocok dengan alat pengocok (Daiki Orbital Shaker) dengan kecepatan 150 rpm pada suhu kamar selama 5 hari. Selanjutnya, campuran disaring dan diencerkan sampai kepadatan yang diinginkan (Soesanto et al., 2005).

Penyiapan medium tanam. Tanah dicangkul lalu dilanjutkan dengan pembuatan guludan. Ukuran guludan $1,20 \times 18 \mathrm{~m}$, dengan tinggi guludan $0,8 \mathrm{~m}$ dan jarak antarguludan $0,8 \mathrm{~m}$. Selanjutnya, pada guludan tersebut dibuat petak percobaan, dengan masing-masing petak berukuran $0,5 \mathrm{~m}^{2}$ untuk 21 rumpun tanaman bawang merah. Pemberian pupuk dilakukan baik dengan pupuk anorganik maupun organik untuk mendukung pertumbuhan tanaman bawang merah. Pupuk organik yang digunakan adalah pupuk kompos dengan dosis 5 ton/Ha, untuk pupuk anorganik digunakan pupuk DAP $200 \mathrm{~kg} / \mathrm{Ha}$, NPK $500 \mathrm{~kg} / \mathrm{Ha}$ dan KAMAS $\left(\mathrm{KNO}_{3}\right) 150 \mathrm{~kg}$.

Pemberian perlakuan antagonis. Percobaan dilakukan menggunakan Rancangan Split-Split Plot yang disusun dalam Rancangan Acak Kelompok. Petak utama adalah tanpa inokulasi dan inokulasi dengan $F$. oxysporum sebanyak $10 \mathrm{~mL}$ per tanaman dengan kepadatan $10^{7}$ konidium/ml larutan. Sebagai anak petak adalah bibit bawang merah direndam selama 30 menit atau disiram sebanyak $10 \mathrm{~mL}$ larutan/tanaman setelah bibit ditanam, sedangkan anak-anak petak adalah tujuh perlakuan, yaitu akuades, benomil dengan konsentrasi $2 \mathrm{~g} / \mathrm{L}$, T.harzianum, $T$. koningii, $P$. fluorescen $\mathrm{P} 60$, gabungan T.harzianum dan P. fluorescen P60, dan gabungan $T$. koningii dan $P$. fluorescen $\mathrm{P} 60$, masingmasing dengan kepadatan $\mathrm{x} \times 10^{7}$ konidium $/ \mathrm{mL}$ larutan. Perlakuan yang dicoba meliputi 28 unit dengan tiga kali ulangan.

Pengamatan. Peubah yang diamati meliputi masa inkubasi (hari setelah inokulasi $=\mathrm{hsi}$ ), intensitas penyakit dengan interval tujuh hari sampai tanaman dipanen, dengan rumus $\mathrm{P}=(\mathrm{A} / \mathrm{N}) \times 100 \%$ (Rosmahani et al., 2003), keterangan: $\mathrm{P}=$ tingkat kerusakan tanaman (\%), $\mathrm{A}=$ jumlah tanaman bergejala, dan $\mathrm{N}=$ jumlah tanaman yang diamati; populasi akhir $F$. oxysporum (Tuite, 1969) dengan rumus $\times .1 / \mathrm{p} .10^{4}$ mikrokonidium $/ \mathrm{ml}(\times$ adalah jumlah mikrokonidium yang dihitung, $\mathrm{p}$ adalah volume pengenceran) dan $2 \times 10^{3}$ makrokonidium $/ \mathrm{mL}$ (penghitungan $\mathrm{p}$ pada kotak besar haemositometer, yaitu A, B, C, D, dan E), bobot basah, bobot kering, tinggi tanaman, jumlah daun, dan jumlah anakan. Data pendukungnya adalah suhu tanah, $\mathrm{pH}$ tanah, dan kelembapan tanah.

Analisis data. Data yang diperoleh dianalisis dengan uji F. Apabila berbeda nyata, dilanjutkan dengan Uji Jarak Berganda Duncan (UJBD) pada taraf kesalahan $5 \%$.

\section{HASIL DAN PEMBAHASAN}

Pengaruh perlakuan terhadap komponen penyakit Pengaruh inokulasi. Hasil sidik ragam menunjukkan tidak ada perbedaan nyata antara petak yang diinokulasi $F$. oxysporum dan petak tanpa inokulasi terhadap masa inkubasi, intensitas penyakit, dan populasi akhir $F$. oxysporum (Tabel 1). Pada petak tanpa inokulasi, pemunculan gejala pertama relatif lebih cepat apabila dibandingkan dengan petak yang tidak diinokulasi. Hal ini diduga karena jamur patogen yang diinokulasi membutuhkan waktu untuk adaptasi.

Tabel 1 juga menunjukkan, intensitas penyakit moler pada petak tanpa inokulasi sebesar 55,59\%, dibandingkan pada petak yang diinokulasi $(66,25 \%)$, meskipun tidak berbeda nyata. Hal ini menunjukkan, pada petak percobaan sudah terdapat inokulum awal, yang membuktikan bahwa lokasi percobaan 
Tabel 1. Pengaruh perlakuan inokulasi terhadap komponen penyakit

\begin{tabular}{cccc}
\hline Perlakuan & Masa inkubasi (hsi) & Intensitas Penyakit $(\%)$ & $\begin{array}{c}\text { Populasi akhir } F . \text { oxysporum } \\
\left(\times 10^{1} \mathrm{upk} / \mathrm{g}\right)\end{array}$ \\
\hline $\mathrm{I}_{0}$ & $21,71 \mathrm{a}$ & $55,59 \mathrm{a}$ & $4,77 \mathrm{a}$ \\
$\mathrm{I}_{\mathrm{i}}$ & $24,60 \mathrm{a}$ & $66,25 \mathrm{a}$ & $4,86 \mathrm{a}$ \\
$\mathrm{R}$ & $21,76 \mathrm{a}$ & $64,46 \mathrm{a}$ & $4,45 \mathrm{a}$ \\
$\mathrm{S}$ & $23,83 \mathrm{~b}$ & $57,37 \mathrm{a}$ & $5,19 \mathrm{a}$ \\
$\mathrm{A}$ & $17,75 \mathrm{e}$ & $70,78 \mathrm{a}$ & $4,84 \mathrm{a}$ \\
$\mathrm{B}$ & $20,58 \mathrm{~d}$ & $57,38 \mathrm{ab}$ & $5,83 \mathrm{a}$ \\
$\mathrm{T}_{1}$ & $23,50 \mathrm{c}$ & $58,42 \mathrm{ab}$ & $4,45 \mathrm{a}$ \\
$\mathrm{T}_{2}$ & $23,50 \mathrm{c}$ & $57,70 \mathrm{~b}$ & $4,17 \mathrm{a}$ \\
$\mathrm{P}$ & $28,42 \mathrm{a}$ & $41,08 \mathrm{~b}$ & $6,00 \mathrm{a}$ \\
$\mathrm{T}_{1} \mathrm{P}$ & $24,83 \mathrm{~b}$ & $63,29 \mathrm{ab}$ & $4,08 \mathrm{a}$ \\
$\mathrm{T}_{2} \mathrm{P}$ & $20,99 \mathrm{~d}$ & $77,79 \mathrm{a}$ & $5,42 \mathrm{a}$ \\
\hline
\end{tabular}

Keterangan: Angka dengan huruf sama pada kolom sama baris sama menunjukkan tidak berbeda nyata menurut UJBD taraf 5\%. Data masa inkubasi ditransformasi ke $\sqrt{x}$, intensitas penyakit ke Arc.Sin $\sqrt{x}$, dan populasi akhir $F$. oxysporum ke $\sqrt{x+0,5} \cdot \mathrm{I}_{0}=\operatorname{tanpa}$ inokulasi, $\mathrm{I}_{\mathrm{i}}=$ inokulasi dengan $F$. oxysporum, $\mathrm{R}=$ rendam, $\mathrm{S}=$ siram, $\mathrm{A}=$ kontrol (akuades), $\mathrm{B}=$ benomil, $\mathrm{T}_{1}=$ T. harzianum, $\mathrm{T}_{2}=T$. koningii, $\mathrm{P}=P$. fluorescen $\mathrm{P} 60, \mathrm{~T}_{1} \mathrm{P}=$ T. harzianum + P. fluorescen $\mathrm{P} 60$, dan $\mathrm{T}_{2} \mathrm{P}=T$. koningii + P. fluorescen P60.

merupakan daerah endemi $F$. oxysporum. Menurut Agrios (2005), Fusarium spp. selalu ada dalam tanah bekas tanaman terserang, baik berupa miselium maupun klamidospora yang berdinding tebal dan bersifat pasif.

Pengaruh rendam atau siram. Perlakuan rendam atau siram berbeda nyata terhadap masa inkubasi, tetapi terhadap intensitas penyakit dan populasi akhir tidak berbeda nyata (Tabel 1). Perlakuan siram mampu memperlambat pemunculan gejala awal 2,07 hsi, yang diduga karena mikroba antagonis yang diinokulasi mampu menyebar, terutama karena adanya aliran siraman. Hal ini sesuai dengan pendapat Davies and Whitbread (1989), bahwa mikroba antagonis dapat bergerak menyebar secara pasif melalui air dengan adanya penyiraman selama pemeliharaan.

Data intensitas penyakit pada perlakuan rendam atau siram tidak berbeda nyata. Hal ini diduga disebabkan oleh faktor biotik dan abiotik yang memengaruhi berbagai tahapan pengolonian antagonis pada permukaan akar atau di sekitar rhizosfer (Pierson and Weller, 1994). Lancar tidaknya tahapan pengolonian memengaruhi daya hambat antagonis terhadap patogen.

Perlakuan rendam atau siram ternyata juga tidak berpengaruh terhadap kepadatan populasi akhir $F$. oxysporum. Akan tetapi, populasi patogen pada perlakuan siram cenderung lebih banyak daripada rendam. Hal ini diduga jumlah antagonis relatif sedikit dibanding jamur patogen, perlu adaptasi dengan lingkungan baru, atau lebih virulennya jamur patogen untuk berkembang. Menurut Agrios (2005), patogen yang virulen mampu dengan cepat menginfeksi inangnya dan selanjutnya menghasilkan inokulum yang lebih banyak daripada patogen yang kurang virulen.

Pengaruh antagonis. Hasil analisis data perlakuan antagonis menunjukkan perbedaan nyata terhadap masa inkubasi dan intensitas penyakit, sedangkan terhadap populasi akhir tidak (Tabel 1). Masa inkubasi tercepat terdapat pada kontrol (A), sebesar 17,75 hsi dan terlama pada pada perlakuan P. fluorescens P60 $(\mathrm{P})$, sebesar 28,42 hsi atau terjadi penundaan sebesar 10,67 hsi atau $62,47 \%$. Cepat munculnya gejala penyakit moler pada kontrol karena keagresifan patogen dalam menimbulkan penyakit serta tidak adanya penghambatan pertumbuhan dan perkembangan patogen. Selain itu, kesesuaian patogen dengan tanaman bawang merah menyebabkan gejala muncul lebih awal. Hal ini sesuai dengan pendapat Maryani (2004), yang menyatakan bahwa masa 
inkubasi yang semakin pendek menunjukkan tingkat kesesuaian patogen inang yang tinggi.

Masa inkubasi terlama pada $P$. fluorescens P60 karena $P$. fluorescens $\mathrm{P} 60$ mampu menghambat pertumbuhan $F$. oxysporum. Penghambatan tersebut kemungkinan sebagai hasil berbagai mekanisme, di antaranya antibiosis, yaitu adanya antibiotika 2,4diasetilfloroglusinol (Phl) yang dihasilkannya (Raaijmakers and Weller, 1998; Soesanto, 2000; Soesanto dan Termorshuizen, 2001).

Tingginya intensitas penyakit pada perlakuan $\mathrm{T}_{2} \mathrm{P}$ dan A diduga disebabkan oleh beberapa faktor, antara lain tersedianya inokulum awal yang tinggi di dalam tanah. Hal ini bertalian dengan lokasi penelitian yang merupakan daerah endemi penyakit moler. Banyaknya jumlah propagul patogen dalam atau dekat tanaman inang memungkinkan lebih banyak inokulum mencapai inang lebih awal, sehingga perubahan epidemi lebih besar (Agrios, 2005). Di samping itu, $T$. koningii belum sesuai dengan P. fluorescens P60 dan perlu adaptasi dengan residu kimia di dalam tanah.

Intensitas penyakit terendah terdapat pada perlakuan $\mathrm{P}$, sebesar $41,08 \%$ atau terjadi penurunan 41,96\%. Hal ini diduga karena $P$. fluorescens P60 mampu menguasai permukaan perakaran secara luas dan menghasilkan antibiotika, sehingga patogen terganggu perkembangannya. Menurut Klopper et al. (1997), P. fluorescens mempunyai kemampuan menempel yang kuat pada permukaan akar, yang didukung hasil penelitian Soesanto (2000).

Meskipun Trichoderma sp. banyak dilaporkan mampu mengendalikan patogen tular-tanah, baik diaplikasikasikan secara tunggal maupun gabungan, tetapi pada percobaan ini, $T$. harzianum dan T. koningii belum mampu menekan intensitas penyakit moler (Tabel 1). Hal ini diduga selain bersaing dengan patogen, $T$. harzianum dan $T$. koningii juga harus bertahan hidup dari pengaruh residu fungisida yang ada dalam tanah, yang sesuai dengan pendapat Agrios (2005). Selain itu, populasi Trichoderma spp. di dalam tanah dipengaruhi oleh faktor fisik, kimia, dan biologi tanah (Papavizas, 1985).

Pengaruh gabungan perlakuan inokulasi dan antagonis terhadap komponen penyakit. Interaksi inokulasi dan antagonis menunjukkan pengaruh sangat nyata hanya pada masa inkubasi dan intensitas penyakit (Tabel 2).

Masa inkubasi tercepat pada petak tanpa inokulasi dan inokulasi terdapat pada kontrol (A), karena bertalian dengan lokasi penelitian sebagai daerah endemi penyakit moler. Masa inkubasi terendah pada petak tanpa inokulasi dan inokulasi terdapat pada perlakuan $\mathrm{P}$ dan terjadi perlambatan masing-masing sebesar 62,33 dan $54,62 \%$. Hal ini sesuai dengan kenyataan bahwa $P$. fluorescens P60 mampu menekan infeksi patogen tular-tanah, misalnya $V$. dahliae pada terung (Soesanto dan Termorshuizen, 2001) dan Sclerotium rolfsii pada kedelai (Soesanto et al., 2003).

Intensitas penyakit tertinggi dijumpai pada perlakuan $\mathrm{I}_{0} \mathrm{~T}_{2} \mathrm{P}$ (Tabel 4), yang diperparah oleh lahan penelitian sebagai daerah endemi penyakit moler. Faktor lain yang mendukung adalah suhu, kelembapan, dan $\mathrm{pH}$ tanah saat penelitian, yaitu masing-masing sebesar $28,5^{\circ} \mathrm{C}, 73 \%$, dan 5,4 . Hal ini sesuai pendapat Domsch et al. (1993) dan Agrios (2005).

Pengaruh gabungan perlakuan rendam atau siram dan antagonis terhadap komponen penyakit. Masa inkubasi tercepat terdapat pada kontrol (A) (Tabel 2) dan terlama pada perlakuan $\mathrm{P}$ dan $\mathrm{T}_{1} \mathrm{P}$ atau terdapat selisih 2,83 hsi. Hal ini diduga peranan $P$. fluorescens P60 dan T. harzianum, yang sesuai dengan pendapat Tronsmo (1996), Raupach. and Kloepper (1998), dan Soesanto (2000).

Intensitas penyakit tertinggi terdapat pada perlakuan $\mathrm{T}_{2} \mathrm{P}$. Hal ini diduga karena $T$. koningii belum sesuai dengan $P$. fluorescens P60 dan harus beradaptasi dengan residu kimia di dalam tanah, sehingga tidak dapat saling mendukung (Agrios, 2005).

Intensitas penyakit terendah perlakuan rendam terdapat pada perlakuan $\mathrm{P}$ atau terjadi penurunan $37,85 \%$. P. fluorescens P60 mampu menekan intensitas penyakit karena mampu mengoloni permukaan akar dari serangan $F$. oxysporum. Hal ini sesuai dengan pendapat Soesanto dan Termorshuizen (2001), yang menyatakan bahwa $P$. fluorescens P60 mampu mengoloni daerah perakaran paling sedikit 12 minggu di dalam berbagai macam medium tanam dengan jumlah koloni yang meningkat, dan lebih banyak terdapat di ujung akar. 
Tabel 2. Pengaruh gabungan perlakuan inokulasi dan antagonis terhadap komponen penyakit

\begin{tabular}{|c|c|c|c|}
\hline Perlakuan & Masa inkubasi (hsi) & Intensitas Penyakit (\%) & $\begin{array}{l}\text { Populasi akhir } F \text {. oxysporum } \\
\qquad\left(\times 10^{1} \mathrm{upk} / \mathrm{g}\right)\end{array}$ \\
\hline $\mathrm{I}_{0} \mathrm{~T}_{1}$ & $20,67 \mathrm{~b}$ & $53,73 \mathrm{ab}$ & $4,00 \mathrm{a}$ \\
\hline $\mathrm{I}_{0} \mathrm{~B}$ & $20,33 \mathrm{~b}$ & $36,87 \mathrm{a}$ & $4,50 \mathrm{a}$ \\
\hline $\mathrm{I}_{0} \mathrm{~T}_{2} \mathrm{P}$ & $19,00 \mathrm{ab}$ & $76,20 \mathrm{c}$ & $4,50 \mathrm{a}$ \\
\hline $\mathrm{I}_{\mathrm{i}} \mathrm{A}$ & $16,84 \mathrm{a}$ & $86,92 \mathrm{c}$ & $4,50 \mathrm{a}$ \\
\hline $\mathrm{I}_{\mathrm{i}} \mathrm{T}_{2}$ & $26,00 \mathrm{c}$ & $52,37 \mathrm{a}$ & $4,17 \mathrm{a}$ \\
\hline $\mathrm{I}_{\mathrm{i}} \mathrm{T}_{1} \mathrm{P}$ & $25,00 \mathrm{c}$ & $67,39 \mathrm{~b}$ & $4,17 \mathrm{a}$ \\
\hline $\mathrm{I}_{\mathrm{i}} \mathrm{P}$ & $30,83 \mathrm{~d}$ & $36,70 \mathrm{a}$ & $4,83 \mathrm{a}$ \\
\hline $\mathrm{I}_{0} \mathrm{~T}_{1} \mathrm{P}$ & $19,33 \mathrm{ab}$ & $59,20 \mathrm{bc}$ & $5,00 \mathrm{a}$ \\
\hline $\mathrm{I}_{0} \mathrm{~A}$ & $18,67 \mathrm{a}$ & $54,63 \mathrm{~b}$ & $5,17 \mathrm{a}$ \\
\hline $\mathrm{I}_{0} \mathrm{~T}_{2}$ & $26,00 \mathrm{c}$ & $63,01 \mathrm{bc}$ & $5,17 \mathrm{a}$ \\
\hline $\mathrm{I}_{\mathrm{i}} \mathrm{T}_{2} \mathrm{P}$ & $21,33 \mathrm{~b}$ & $79,37 \mathrm{bc}$ & $6,33 \mathrm{a}$ \\
\hline $\mathrm{I}_{\mathrm{i}} \mathrm{T}_{1}$ & $26,33 \mathrm{c}$ & $63,10 \mathrm{~b}$ & $6,34 \mathrm{a}$ \\
\hline $\mathrm{I}_{0} \mathrm{P}$ & $30,00 \mathrm{~d}$ & $50,47 \mathrm{ab}$ & $7,17 \mathrm{a}$ \\
\hline $\mathrm{I}_{\mathrm{i}} \mathrm{B}$ & $20,84 \mathrm{~b}$ & $77,90 \mathrm{bc}$ & $7,17 \mathrm{a}$ \\
\hline $\mathrm{RT}_{1}$ & $21,00 \mathrm{c}$ & $47,62 \mathrm{ab}$ & $4,33 \mathrm{a}$ \\
\hline $\mathrm{RP}$ & $30,67 \mathrm{e}$ & 44,69 a & $4,92 \mathrm{a}$ \\
\hline $\mathrm{RT}_{2}$ & $23,67 \mathrm{~d}$ & $66,60 \mathrm{~b}$ & $5,00 \mathrm{a}$ \\
\hline $\mathrm{ST}_{2} \mathrm{P}$ & $22,83 \mathrm{~b}$ & $73,04 \mathrm{~b}$ & $5,00 \mathrm{a}$ \\
\hline $\mathrm{ST}_{2}$ & $26,00 \mathrm{c}$ & $69,22 \mathrm{~b}$ & $5,07 \mathrm{a}$ \\
\hline RA & $17,40 \mathrm{a}$ & $74,60 \mathrm{~b}$ & $5,34 \mathrm{a}$ \\
\hline $\mathrm{RT}_{1} \mathrm{P}$ & $21,83 \mathrm{c}$ & $67,59 \mathrm{~b}$ & $5,58 \mathrm{a}$ \\
\hline $\mathrm{ST}_{1} \mathrm{P}$ & $27,84 \mathrm{~d}$ & $59,00 \mathrm{~b}$ & $5,67 \mathrm{a}$ \\
\hline $\mathrm{RT}_{2} \mathrm{P}$ & $19,17 \mathrm{~b}$ & $82,54 \mathrm{~b}$ & $5,84 \mathrm{a}$ \\
\hline SP & $23,34 \mathrm{~b}$ & $48,76 \mathrm{ab}$ & $6,00 \mathrm{a}$ \\
\hline SB & $22,50 \mathrm{~b}$ & $47,15 \mathrm{a}$ & $6,92 \mathrm{a}$ \\
\hline SA & $18,17 \mathrm{a}$ & $66,95 \mathrm{~b}$ & $7,09 \mathrm{a}$ \\
\hline $\mathrm{RB}$ & $18,67 a b$ & $67,62 \mathrm{~b}$ & $7,67 \mathrm{a}$ \\
\hline $\mathrm{ST}_{1}$ & $26,17 \mathrm{c}$ & $37,48 \mathrm{a}$ & $9,84 \mathrm{a}$ \\
\hline
\end{tabular}

Keterangan: Angka yang diikuti huruf yang sama pada kolom sama baris sama menunjukkan tidak berbeda nyata menurut UJBD taraf 5\%. Data masa inkubasi ditransformasi ke $\sqrt{x}$, intensitas penyakit ke Arc.Sin $\sqrt{x}$, dan $\sqrt{x+0,5} \cdot \mathrm{I}_{0}=$ tanpa inokulasi, $\mathrm{I}_{\mathrm{i}}=$ inokulasi dengan $F$. oxysporum, $\mathrm{R}=$ rendam, $\mathrm{S}=$ siram, $\mathrm{A}=$ kontrol (akuades), $\mathrm{B}=$ benomil, $\mathrm{T}_{1}=$ T. harzianum, $\mathrm{T}_{2}=T$. koningii, $\mathrm{P}=P$. fluorescen $\mathrm{P} 60, \mathrm{~T}_{1} \mathrm{P}=$ T. harzianum + P. fluorescen $\mathrm{P} 60$, dan $\mathrm{T}_{2} \mathrm{P}=T$. koningii $+P$. fluorescen $\mathrm{P} 60$.

Pengaruh gabungan perlakuan inokulasi, rendam atau siram dan antagonis terhadap komponen penyakit. Masa inkubasi tercepat terdapat pada perlakuan A (kontrol). Cepatnya masa inkubasi tersebut diduga karena beberapa faktor, seperti keagresifan patogen dalam menimbulkan penyakit dan tidak adanya penghambatan patogen oleh mikroba lain. Juga karena kesesuaian patogen dengan tanaman bawang merah yang tinggi (Maryani et al., 2005). Masa inkubasi terlama terdapat pada perlakuan
P. fluorescens P60 (P) di semua petak. Hal ini karena kemampuan $P$. fluorescens P60 dalam menghambat patogen, sesuai pendapat Soesanto (2000), Soesanto \& Termorshuizen (2001), Soesanto et al. (2003), dan Rokhlani (2005). Sementara itu, belum optimumnya daya tekan $T$. harzianum dan $T$. koningii terhadap $F$. oxysporum diduga kedua antagonis tersebut kurang mampu beradaptasi dengan residu bahan kimia sintetis di dalam tanah. 
Tabel 3. Pengaruh gabungan perlakuan inokulasi, rendam atau siram dan antagonis terhadap komponen penyakit

\begin{tabular}{|c|c|c|c|}
\hline Perlakuan & Masa inkubasi (hsi) & Intensitas Penyakit (\%) & $\begin{array}{c}\text { Populasi akhir } F \text {. oxysporum } \\
\left(\times 10^{1} \mathrm{upk} / \mathrm{g}\right)\end{array}$ \\
\hline $\mathrm{I}_{\mathrm{i}} \mathrm{RT}_{2}$ & $26,33 \mathrm{~d}$ & $49,35 \mathrm{a}$ & $6,17 \mathrm{a}$ \\
\hline $\mathrm{I}_{0} \mathrm{RT}_{1}$ & $18,33 \mathrm{c}$ & 73,79 a & $6,33 \mathrm{a}$ \\
\hline $\mathrm{I}_{0} \mathrm{RT} 2 \mathrm{P}$ & $19,00 \mathrm{~b}$ & $85,70 \mathrm{a}$ & $7,00 \mathrm{a}$ \\
\hline $\mathrm{I}_{0} \mathrm{RP}$ & $30,00 \mathrm{a}$ & 81,87 a & $7,00 \mathrm{a}$ \\
\hline $\mathrm{I}_{0} \mathrm{RT}_{2}$ & $21,00 \mathrm{~b}$ & 84,08 a & $7,17 \mathrm{a}$ \\
\hline $\mathrm{I}_{0} \mathrm{RB}$ & $20,33 \mathrm{~b}$ & $79,44 \mathrm{a}$ & $7,67 \mathrm{a}$ \\
\hline $\mathrm{I}_{0} \mathrm{RT} 1 \mathrm{P}$ & $19,33 \mathrm{~b}$ & 83,12 a & $7,67 \mathrm{a}$ \\
\hline $\mathrm{I}_{\mathrm{i}} \mathrm{RT}_{2} \mathrm{P}$ & $19,33 \mathrm{~b}$ & $88,37 \mathrm{a}$ & $7,67 \mathrm{a}$ \\
\hline $\mathrm{I}_{\mathrm{i}} \mathrm{RB}$ & $17,00 \mathrm{c}$ & $96,83 \mathrm{a}$ & $7,95 \mathrm{a}$ \\
\hline $\mathrm{I}_{\mathrm{i}} \mathrm{RT}_{1}$ & $23,67 \mathrm{e}$ & $70,65 \mathrm{a}$ & $8,00 \mathrm{a}$ \\
\hline $\mathrm{I}_{0} \mathrm{RA}$ & $17,67 \mathrm{c}$ & 77,78 a & $5,67 \mathrm{a}$ \\
\hline $\mathrm{I}_{\mathrm{i}} \mathrm{RA}$ & $17,00 \mathrm{c}$ & $90,47 \mathrm{a}$ & $8,33 \mathrm{a}$ \\
\hline $\mathrm{I}_{\mathrm{i}} \mathrm{RP}$ & $31,33 \mathrm{a}$ & $69,05 \mathrm{a}$ & $9,83 \mathrm{a}$ \\
\hline $\mathrm{I}_{\mathrm{i}} \mathrm{RT}_{1} \mathrm{P}$ & $24,33 \mathrm{e}$ & $65,77 \mathrm{a}$ & $10,33 \mathrm{a}$ \\
\hline $\mathrm{I}_{0} \mathrm{SB}$ & $20,33 \mathrm{c}$ & $51,01 \mathrm{a}$ & $7,00 \mathrm{a}$ \\
\hline $\mathrm{I}_{0} \mathrm{SA}$ & $19,67 \mathrm{c}$ & $50,53 \mathrm{a}$ & $7,34 \mathrm{a}$ \\
\hline $\mathrm{I}_{0} \mathrm{ST} 1 \mathrm{P}$ & $30,00 \mathrm{~b}$ & $49,00 \mathrm{a}$ & $7,84 \mathrm{a}$ \\
\hline $\mathrm{I}_{0} \mathrm{ST} 2 \mathrm{P}$ & $22,33 \mathrm{a}$ & $66,70 \mathrm{a}$ & $8,00 \mathrm{a}$ \\
\hline $\mathrm{I}_{\mathrm{i}} \mathrm{ST}_{2}$ & $25,67 \mathrm{~b}$ & $62,30 \mathrm{a}$ & 8,17 a \\
\hline $\mathrm{I}_{0} \mathrm{ST}_{1}$ & $23,00 \mathrm{a}$ & $56,70 \mathrm{a}$ & $8,42 \mathrm{a}$ \\
\hline $\mathrm{I}_{\mathrm{i}} \mathrm{ST}_{1}$ & $29,00 \mathrm{a}$ & 81,73 a & $8,00 \mathrm{a}$ \\
\hline $\mathrm{I}_{0} \mathrm{ST}_{2}$ & $21,00 \mathrm{c}$ & $54,70 \mathrm{a}$ & $8,00 \mathrm{a}$ \\
\hline $\mathrm{I}_{\mathrm{i}} \mathrm{ST}_{1}$ & $29,00 \mathrm{a}$ & $81,73 \mathrm{a}$ & $8,00 \mathrm{a}$ \\
\hline $\mathrm{I}_{\mathrm{i}} \mathrm{SA}$ & $16,67 \mathrm{c}$ & $83,37 \mathrm{a}$ & $8,61 \mathrm{a}$ \\
\hline $\mathrm{I}_{\mathrm{i}} \mathrm{SB}$ & $24,67 \mathrm{~d}$ & $58,97 \mathrm{a}$ & $8,61 \mathrm{a}$ \\
\hline $\mathrm{I}_{\mathrm{i}} \mathrm{ST}_{1} \mathrm{P}$ & $25,67 \mathrm{~b}$ & $69,00 \mathrm{a}$ & $8,76 \mathrm{a}$ \\
\hline $\mathrm{I}_{\mathrm{i}} \mathrm{ST}_{2} \mathrm{P}$ & $23,33 \mathrm{bd}$ & $79,37 \mathrm{a}$ & $8,76 \mathrm{a}$ \\
\hline $\mathrm{I}_{\mathrm{i}} \mathrm{SP}$ & 30,33 a & $57,75 \mathrm{a}$ & $9,83 \mathrm{a}$ \\
\hline $\mathrm{I}_{0} \mathrm{SP}$ & $22,00 \mathrm{a}$ & $42,83 \mathrm{a}$ & $10,67 \mathrm{a}$ \\
\hline
\end{tabular}

Keterangan: Angka yang diikuti huruf yang sama pada kolom per baris yang sama menunjukkan tidak berbeda nyata menurut UJBD taraf 5\% untuk kelompok pembanding yang sama. Data masa inkubasi ditransformasi ke $\sqrt{x}$, intensitas penyakit ditransformasi ke Arc.Sin $\sqrt{x}$, dan populasi akhir $F$. oxysporum ke $\sqrt{x+0,5}$.

\footnotetext{
Pengaruh perlakuan terhadap komponen pertumbuhan.

Pengaruh perlakuan inokulasi terhadap komponen pertumbuhan. Semua komponen pertumbuhan yang diukur pada petak diinokulasi lebih tinggi apabila dibandingkan dengan petak tanpa inokulasi, meskipun tidak berbeda nyata (Tabel 4). Inokulasi $F$. oxysporum diduga menyebabkan bawang merah lebih mudah terinfeksi yang memungkinkan terjadi perubahan fisiologi. Hal ini sesuai dengan pendapat Agrios (2005).
}

\footnotetext{
Pengaruh perlakuan rendam atau siram terhadap komponen pertumbuhan. Perlakuan rendam atau siram berpengaruh sangat nyata terhadap bobot basah dan bobot kering tanaman bawang merah, tetapi tidak berpengaruh terhadap komponen pertumbuhan lain (Tabel 4). Hal ini makin membuktikan bahwa lahan yang digunakan telah terkontaminasi $F$. oxysporum, yang selaras dengan tingginya intensitas penyakit pada kedua perlakuan tersebut yang tidak berbeda nyata. Sesuai dengan pendapat Agrios (2005).
} 
Tabel 4. Pengaruh perlakuan inokulasi terhadap komponen pertumbuhan

\begin{tabular}{lccccc}
\hline Perlakuan & $\begin{array}{c}\text { Bobot Basah } \\
(\text { g/petak })\end{array}$ & $\begin{array}{c}\text { Bobot Kering } \\
(\text { g/petak }\end{array}$ & $\begin{array}{c}\text { Tinggi Tanaman } \\
(\mathrm{cm})\end{array}$ & $\begin{array}{c}\text { Jumlah Daun } \\
(\text { helai) }\end{array}$ & $\begin{array}{c}\text { Jumlah anakan } \\
\text { (buah) }\end{array}$ \\
\hline $\mathrm{I}_{0}$ & $681,01 \mathrm{a}$ & $390,67 \mathrm{a}$ & $28,87 \mathrm{a}$ & $21,34 \mathrm{a}$ & $5,56 \mathrm{a}$ \\
$\mathrm{I}_{\mathrm{i}}$ & $522,16 \mathrm{a}$ & $272,35 \mathrm{a}$ & $26,27 \mathrm{a}$ & $15,46 \mathrm{a}$ & $5,51 \mathrm{a}$ \\
\hline $\mathrm{R}$ & $635,23 \mathrm{a}$ & $341,23 \mathrm{a}$ & $26,33 \mathrm{a}$ & $18,06 \mathrm{a}$ & $6,16 \mathrm{a}$ \\
$\mathrm{S}$ & $576,94 \mathrm{~b}$ & $321,78 \mathrm{~b}$ & $28,81 \mathrm{a}$ & $18,75 \mathrm{a}$ & $8,91 \mathrm{a}$ \\
\hline $\mathrm{A}$ & $379,60 \mathrm{a}$ & $265,67 \mathrm{ab}$ & $24,92 \mathrm{a}$ & $16,02 \mathrm{ab}$ & $5,67 \mathrm{a}$ \\
$\mathrm{B}$ & $538,86 \mathrm{ab}$ & $289,95 \mathrm{ab}$ & $26,68 \mathrm{a}$ & $13,46 \mathrm{a}$ & $6,47 \mathrm{a}$ \\
$\mathrm{T}_{1}$ & $623,23 \mathrm{~b}$ & $391,62 \mathrm{~b}$ & $26,78 \mathrm{a}$ & $19,07 \mathrm{ab}$ & $5,99 \mathrm{a}$ \\
$\mathrm{T}_{2}$ & $678,76 \mathrm{~b}$ & $351,58 \mathrm{~b}$ & $29,10 \mathrm{a}$ & $21,07 \mathrm{~b}$ & $6,15 \mathrm{a}$ \\
$\mathrm{P}$ & $781,16 \mathrm{~b}$ & $405,15 \mathrm{~b}$ & $30,41 \mathrm{a}$ & $24,98 \mathrm{~b}$ & $5,98 \mathrm{a}$ \\
$\mathrm{T}_{1} \mathrm{P}$ & $694,14 \mathrm{~b}$ & $407,26 \mathrm{~b}$ & $29,20 \mathrm{a}$ & $18,63 \mathrm{a}$ & $5,23 \mathrm{a}$ \\
$\mathrm{T}_{2} \mathrm{P}$ & $389,40 \mathrm{a}$ & $210,34 \mathrm{a}$ & $28,44 \mathrm{ab}$ & $15,62 \mathrm{a}$ & $6,00 \mathrm{a}$ \\
\hline $\mathrm{I}_{0} \mathrm{~A}$ & $620,55 \mathrm{a}$ & $346,16 \mathrm{a}$ & $28,25 \mathrm{ab}$ & $23,50 \mathrm{ab}$ & $6,64 \mathrm{a}$ \\
$\mathrm{I}_{0} \mathrm{~B}$ & $744,35 \mathrm{a}$ & $424,92 \mathrm{a}$ & $30,82 \mathrm{ab}$ & $19,23 \mathrm{ab}$ & $7,20 \mathrm{a}$ \\
$\mathrm{I}_{0} \mathrm{~T}_{1}$ & $688,28 \mathrm{a}$ & $372,34 \mathrm{a}$ & $29,02 \mathrm{ab}$ & $22,10 \mathrm{ab}$ & $6,47 \mathrm{a}$ \\
$\mathrm{I}_{0} \mathrm{~T}_{2}$ & $648,86 \mathrm{a}$ & $340,16 \mathrm{a}$ & $27,14 \mathrm{a}$ & $17,10 \mathrm{a}$ & $6,10 \mathrm{a}$ \\
$\mathrm{I}_{0} \mathrm{P}$ & $803,46 \mathrm{a}$ & $536,37 \mathrm{a}$ & $30,77 \mathrm{ab}$ & $26,10 \mathrm{~b}$ & $6,27 \mathrm{a}$ \\
$\mathrm{I}_{0} \mathrm{~T}_{1} \mathrm{P}$ & $797,46 \mathrm{a}$ & $485,27 \mathrm{a}$ & $29,98 \mathrm{ab}$ & $23,79 \mathrm{ab}$ & $5,23 \mathrm{a}$ \\
$\mathrm{I}_{0} \mathrm{~T}_{2} \mathrm{P}$ & $689,01 \mathrm{a}$ & $358,39 \mathrm{a}$ & $30,85 \mathrm{~b}$ & $17,49 \mathrm{ab}$ & $6,50 \mathrm{a}$ \\
$\mathrm{I}_{\mathrm{i}} \mathrm{A}$ & $594,06 \mathrm{a}$ & $335,23 \mathrm{a}$ & $21,56 \mathrm{a}$ & $8,53 \mathrm{ab}$ & $4,50 \mathrm{a}$ \\
$\mathrm{I}_{\mathrm{i}} \mathrm{B}$ & $565,37 \mathrm{a}$ & $320,13 \mathrm{a}$ & $22,55 \mathrm{a}$ & $7,63 \mathrm{a}$ & $7,17 \mathrm{a}$ \\
$\mathrm{I}_{\mathrm{i}} \mathrm{T}_{1}$ & $558,19 \mathrm{a}$ & $410,89 \mathrm{a}$ & $24,28 \mathrm{a}$ & $16,04 \mathrm{~b}$ & $6,34 \mathrm{a}$ \\
$\mathrm{I}_{\mathrm{i}} \mathrm{T}_{2}$ & $708,66 \mathrm{a}$ & $363,01 \mathrm{a}$ & $31,07 \mathrm{c}$ & $25,04 \mathrm{c}$ & $4,17 \mathrm{a}$ \\
$\mathrm{I}_{\mathrm{i}} \mathrm{P}$ & $758,74 \mathrm{a}$ & $379,60 \mathrm{a}$ & $30,05 \mathrm{c}$ & $23,87 \mathrm{c}$ & $4,83 \mathrm{a}$ \\
$\mathrm{I}_{\mathrm{i}} \mathrm{T}_{1} \mathrm{P}$ & $590,82 \mathrm{a}$ & $329,25 \mathrm{a}$ & $28,42 \mathrm{bc}$ & $13,47 \mathrm{ab}$ & $4,17 \mathrm{a}$ \\
$\mathrm{I}_{\mathrm{i}} \mathrm{T}_{2} \mathrm{P}$ & $556,10 \mathrm{a}$ & $337,23 \mathrm{a}$ & $25,97 \mathrm{~b}$ & $13,75 \mathrm{ab}$ & $6,33 \mathrm{a}$ \\
\hline
\end{tabular}

Keterangan: Angka yang diikuti huruf yang sama pada kolom sama baris sama menunjukkan tidak berbeda nyata menurut UJBD taraf 5\%. Bobot basah, bobot kering, tinggi tanaman ditransformasi ke $\sqrt{x}$, jumlah daun dan anakan ke $\sqrt{x+0,5}$. Keterangan lain sama dengan tabel sebelumnya.

Pengaruh perlakuan antagonis terhadap komponen pertumbuhan. Perlakuan antagonis berpengaruh nyata terhadap bobot basah dan jumlah daun bawang merah, berpengaruh sangat nyata terhadap bobot kering tanaman bawang merah, dan tidak berpengaruh terhadap tinggi tanaman dan jumlah anakan.

Jumlah daun terbanyak terdapat pada perlakuan $\mathrm{P}$ dan terkecil pada perlakuan B. Hal ini diduga karena P. fluorescens P60 yang diinokulasi ke dalam tanah, mampu berperan sebagai agensia hayati maupun sebagai PGPR., yang merangsang pertumbuhan sistem akar dan menghambat jamur dan bakteri yang merugikan (Weller, 1988). Rendahnya jumlah daun pada perlakuan B selaras dengan ketakmampuan fungisida untuk mengendalikan patogen, yang berakibat pada tingginya intensitas penyakit dan berpengaruh pada pertumbuhan tanaman. Suhardi et al. (1979 dalam Semangun, 2000) mengatakan bahwa beberapa usaha untuk mengendalikan penyakit layu fusarium pada tomat dengan fungisida tidak memberikan hasil yang mememuaskan.

Bobot basah tanaman tertinggi terdapat pada perlakuan $\mathrm{P}$ dan terendah terdapat pada perlakuan $\mathrm{A}$ atau terdapat selisih 401,56 g. Tingginya bobot basah tanaman pada perlakuan $\mathrm{P}$ diduga karena peranan P. fluorescens P60 dalam merangsang pertumbuhan tanaman selain mampu menekan patogen. Menurut Dowling dan O' Gara (1994), P. fluorescens menghasilkan siderofor, senyawa antimikroba, dan hormon tumbuh, sehingga dapat merangsang pertumbuhan tanaman. Perlakuan gabungan T. koningii dan P. fluorescens P60 belum sesuai, sehingga perlindungan tanaman bawang merah kurang 
optimum. Bobot kering tanaman tertinggi terdapat pada perlakuan $\mathrm{P}$ dan $\mathrm{T}_{1} \mathrm{P}$, sedangkan terendah pada perlakuan $\mathrm{T}_{2} \mathrm{P}$ dan $\mathrm{A}$, atau terjadi peningkatan bobot kering tanaman masing-masing sebesar 51,92 dan $51,63 \%$, bila dibandingkan dengan $\mathrm{T}_{2} \mathrm{P}$ dan $\mathrm{A}$. Hal ini selaras dengan tingginya bobot basah tanaman bawang merah.

Perlakuan $P$. fluorescens $\mathrm{P} 60$ baik secara tunggal maupun gabungan dengan $T$. harzianum mampu meningkatkan bobot kering tanaman bawang merah. Hal ini menunjukkan adanya kesesuaian antara P. fluorescens P60 dengan T. harzianum, yang sesuai dengan Rokhlani (2005). Menurut Dowling dan O'Gara (1994), pada kondisi $\mathrm{Fe}^{3+}$ terbatas, $P$. fluorescens mampu mengikatnya dengan kuat karena adanya senyawa siderofor. Besi merupakan unsur penting pertumbuhan, karena berfungsi sebagai kofaktor enzim oksidasi dan reduksi. Banyak patogen membutuhkan besi sebagai nutrisi penting untuk kevirulenannya, sehingga produksi siderofor menyebabkan $\mathrm{Fe}^{3+}$ tidak tersedia bagi patogen. Akibatnya, patogen dapat ditekan dan tanaman dapat tumbuh dengan optimum, sehingga berat kering menjadi besar.

\section{Pengaruh gabungan inokulasi dan perlakuan antagonis terhadap komponen pertumbuhan. Jumlah daun tertinggi terdapat pada perlakuan $\mathrm{P}$ dan terendah pada $T_{2}$ (Tabel 4). Tingginya jumlah daun dan tinggi tanaman pada perlakuan $\mathrm{P}$ diduga karena $P$. fluorescens P60 sebagai Plant Growth Promoting Rhizobacteria (PGPR). Hal ini terbukti dari hasil penelitian Riswanto (2003). P. fluorescens menghasilkan hormon tanaman, yaitu asam salisilat dan asam indol asetat (IAA) (Dowling dan O' Gara, 1994), yang merupakan bioaktif dan merangsang perpanjangan akar.}

Pengaruh gabungan rendam atau siram dan perlakuan antagonis serta gabungan perlakuan inokulasi dan antagonis terhadap komponen pertumbuhan. Interaksi perlakuan rendam atau siram dan perlakuan antagonis serta perlakuan inokulasi, rendam atau siram dan perlakuan antagonis tidak berpengaruh nyata terhadap komponen pertumbuhan.

\section{SIMPULAN}

1. Penekanan hayati menggunakan P. fluorescens P60 baik secara tunggal atau gabungan lebih efektif terhadap penyakit moler dibandingkan dengan
T. harzianum dan T. koningii. P. fluorescens P60 mampu menekan intensitas penyakit $41,96 \%$.

2. Pseudomonas fluorescens P60 terbaik diberikan secara siram sebanyak $10 \mathrm{~mL}$ dengan kepadatan $10^{7}$ upk/mL yang mampu menurunkan masa inkubasi dan intensitas penyakit dan memperkecil populasi patogen masing-masing $5,17 \mathrm{hsi}, 18,19 \%$, dan $1,09 \times 10^{1} \mathrm{upk} / \mathrm{g}$ tanah.

3. Pertumbuhan dan produksi bawang merah cenderung meningkat akibat penekanan hayati oleh $P$. fluorescens P60 sebesar 65,57\%, sedangkan T. harzianum dan T. koningii tidak mampu.

\section{DAFTAR PUSTAKA}

Agrios, G.N. 2005. Plant Pathology $5^{\text {th }}$ ed. Elsevier Academic Press, San Diego. 922 p.

Badan Pusat Statistik. 2004. Kabupaten Tegal Dalam Angka. Pemerintah Daerah Kabupaten Tegal.

Davies, K.G. \& R. Whitbread. 1989. A comparation or methods of the colonisation of root system by fluorescens Pseudomonads. Plant and Soil 116:339-241.

Departemen Pertanian. 2003. Metode Pengamatan OPT Tanaman Sayuran. (On-line). http://www.deptan.go.id diakses 1 Maret 2006.

Domsch, K.H., W. Gams, \& T.H Anderson. 1993. Compendium of Soil Fungi. Volume 1. IHWVerlag, Eching. Pp. 305-799.

Dowling, D.N. \& F. O'Gara. 1994. Metabolites of Pseudomonas involved in the biocontrol of plant disease. Tibtech. 12:133-141.

Kloepper, J.W., S. Tuzun, G.W. Zehnder, \& G. Wei. 1997. Multiple disease protection by rhizobacteria that induce systemic resistance - Historical precedence. Phytopathol. 87(2):136-137.

Maryani, A.D., L. Soesanto, \& T. Agung D.H. 2005. Kajian ketahanan terhadap penyakit trotol dan struktur anatomi daun dari lima kultivar bawang merah (Allium ascalonicum L.). Tropika 13(2):113-121. 
Papavizas, G.C. 1985. Trichoderma and Gliocladium: biology, ecology, and potential for biocontrol. Ann. Rev. Phytopathology 23:23-54.

Pierson, E.A. \& D.M. Weller. 1994. Use of mixtures of fluorescens Pseudomonads to suppress take-all and improve the growth of wheat. Phytopathology 84:940-947.

Prabowo, A.K.E., N. Prihatiningsih, \& L. Soesanto. 2006. Potensi Trichoderma harzianum dalam mengendalikan sembilan isolat Fusarium oxysporum Schlecht. f.sp. zingiberi Trujillo pada kencur. Jurnal Ilmu-Ilmu Pertanian Indonesia 8(2):76-84.

Raaijmakers, J.M. \& D.M. Weller. 1998. Natural plant protection by 2,4-diacetylphloroglucinolproducing Pseudomonas spp. on take-all decline soils. MPMI 11(2):144-152.

Raupach, G.S. and J.W. Kloepper. 1998. Mixture of plant growth-promoting rhizobacteria enhance biological control of multiple cucumber pathogens. Phytopathol. 88:11581164.

Rokhlani. 2005. Potensi Pseudomonas fluorescens P60, Trichoderma harzianum, dan Gliocladium sp. Dalam Menekan Fusarium oxysporum f.sp. gladioli In Vitro dan In Planta. Skripsi. Fakultas Pertanian Universitas Jenderal Soedirman, Purwokerto. 58 hal. (Tidak Dipublikasikan).

Rosmahani, I., E. Korlina, Baswarsiati, E. Retnaningtyas, A. Suryadi, S.Z. Sa'adah, \& Sukur. 2003. Sistem Usaha Tani Berbasis Bawang Merah di Lahan Kering Dataran Rendah (On-line). http://www.bbptjatim.deptan.go.id diakses 1 Maret 2006.

Semangun, H. 2000. Penyakit-penyakit Tanaman Hortikultura di Indonesia. Gadjah Mada University Press, Yogyakarta. 850 hal.
Soesanto, L. 2000. Ecology and Biological Control of Verticillium dahliae. Ph.D. Thesis. Wageningen University, Wageningen. 120 p.

Soesanto, L. \& A.J. Termorshuizen. 2001. Potensi Pseudomonas fluorescens P60 sebagai agensia hayati jamur-jamur patogen tulartanah. Prosiding Kongres XIV dan Seminar Nasional PFI, Bogor. Hal. 183-186.

Soesanto, L., E. Pramono, D.S. Utami, \& A. Riswanto 2003. Potensi Pseudomonas fluorescens P60 sebagai agensia pengendali hayati Sclerotium rolfsii Sacc. pada tanaman kedelai. Prosiding Kongres XVII dan Seminar Nasional Perhimpunan Fitopatologi Indonesia, Bandung, 6-8 Agustus 2003.

Soesanto, L., Soedharmono, N. Prihatiningsih, A. Manan, E. Iriani, \& J. Pramono. 2005. potensi agensia hayati dan nabati dalam mengendalikan penyakit busuk rimpang jahe. Jurnal Hama dan Penyakit Tumbuhan Tropika 5(1):50-57.

Sudantha, I.D. 2003. Pengaruh kadar air tanah tersedia terhadap aktivitas jamur Trichoderma harzianum dalam menekan jamur Sclerotium rolfsii pada tanaman kedelai. Jurnal Penelitian 2(4):24-30.

Tronsmo, A. 1996. Trichoderma harzianum in Biological Control of Fungal Diseases. Pp. 212-221. In: R. Hall (ed.), Principles And Practise of Managing Soil Borne Plant Pathogens. APS Press, St. Paul, Minenesota.

Tuite, J. 1969. Plant Pathological Method: Fungi and Bacteria. Burgess Publishing Company, Minneapolis.

Weller, D.M. 1988. Biological control of soil-borne plant pathogens in the rhizosphere with bacteria. Ann. Rev. Phytopathol. 26:379-407. 